U.S. Department of the Interior

U.S. Geological Survey

\title{
Evaluation OF GEOPHYSICAL LOGS, PHASE I, FOR CROSSLEY FARMS SUPERFUND SITE, Berks County, Pennsylvania
}

by Randall W. Conger

Open-File Report 98-62

prepared in cooperation with the

U.S. ENVIRONMENTAL PROTECTION AGENCY 


\title{
U.S. DEPARTMENT OF THE INTERIOR
}

\author{
BRUCE BABBITT, Secretary
}

\author{
U.S. GEOLOGICAL SURVEY
}

Thomas J. Casadevall, Acting Director

For additional information write to:

District Chief

U.S. Geological Survey 840 Market Street

Lemoyne, Pennsylvania 17043-1584
Copies of this report may be purchased from:

U.S. Geological Survey

Branch of Information Services

Box 25286, Building 810

Denver, Colorado 80225-0286 


\section{CONTENTS}

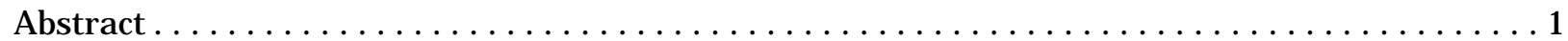

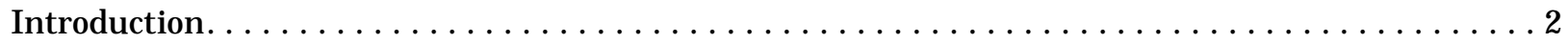

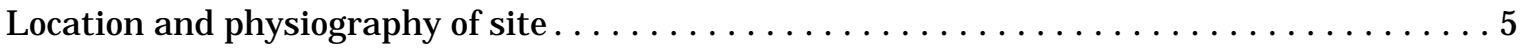

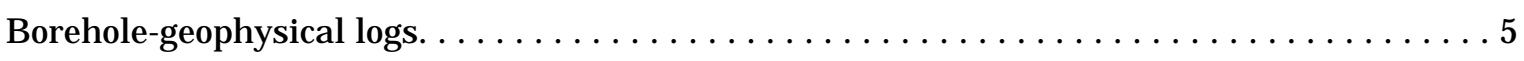

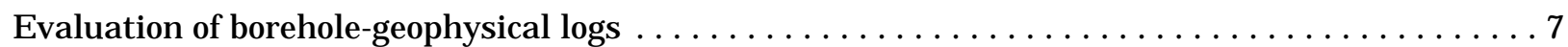

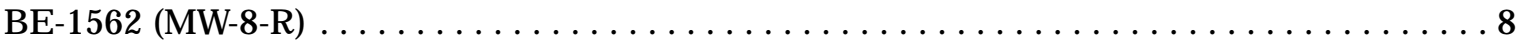

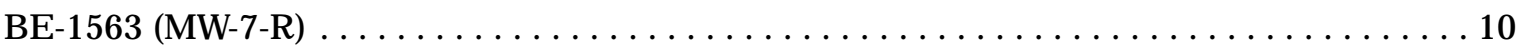

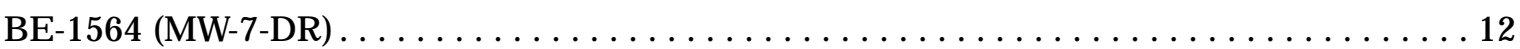

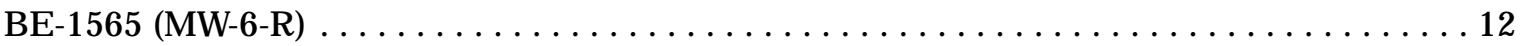

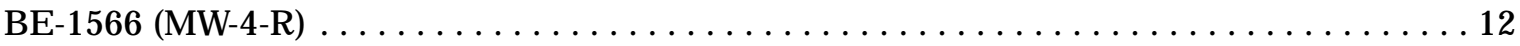

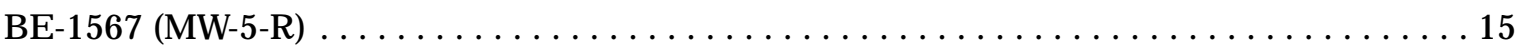

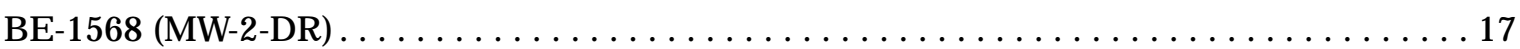

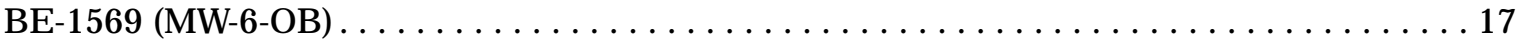

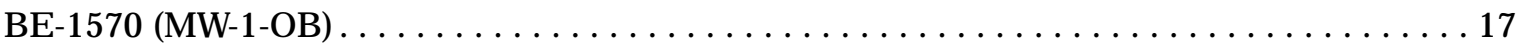

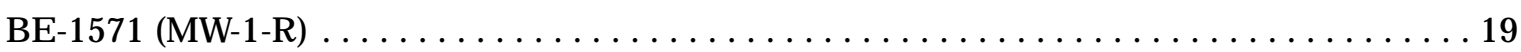

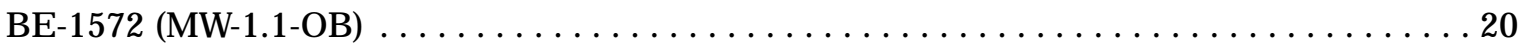

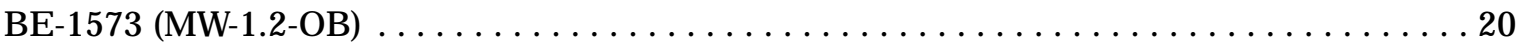

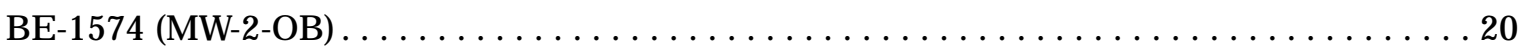

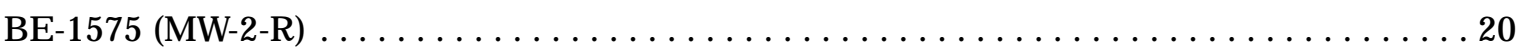

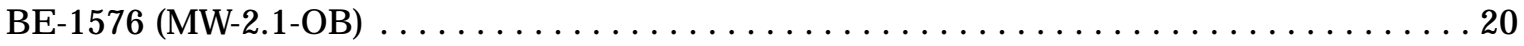

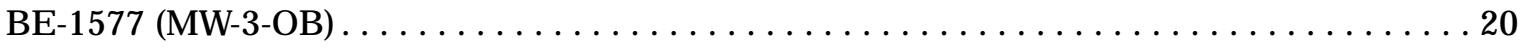

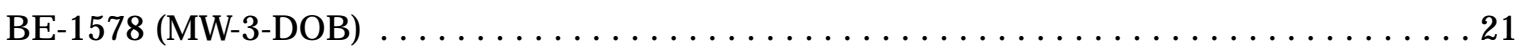

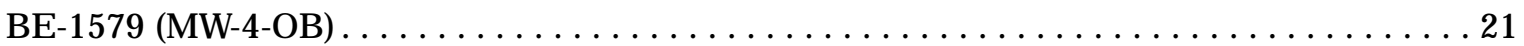

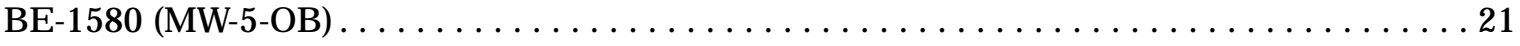

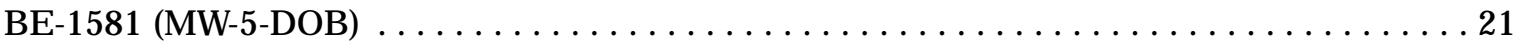

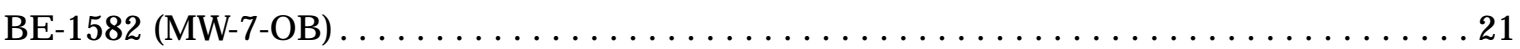

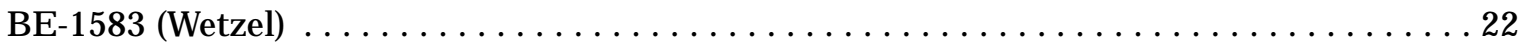

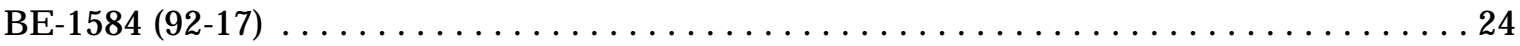

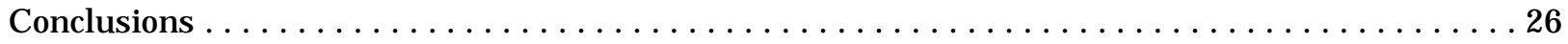

References cited. . . . . . . . . . . . . . . . . . . . . 26 


\section{ILLUSTRATIONS}

Page

Figure 1. Map showing locations of boreholes logged at the Crossley Farms Superfund Site,

Berks County, Pennsylvania . . . . . . . . . . . . . . . . . . 3

2-11. Graphs showing borehole-geophysical logs for boreholes at the Crossley Farms Superfund Site, Berks County, Pennsylvania:

2. BE-1562 (MW-8-R), collected on April $24,1997 \ldots \ldots \ldots \ldots \ldots \ldots \ldots$

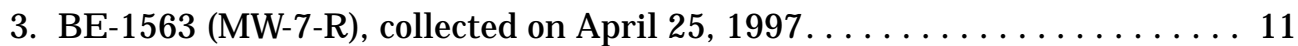

4. BE-1564 (MW-7-DR), collected on April 25, $1997 \ldots \ldots \ldots \ldots \ldots \ldots \ldots$

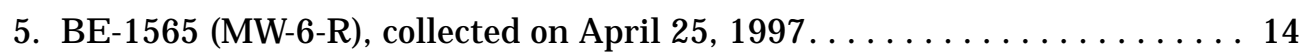

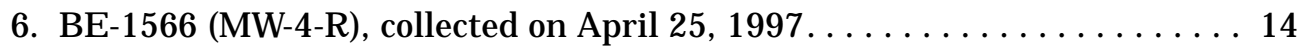

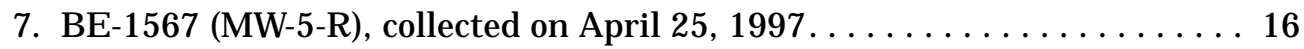

8. BE-1568 (MW-2-DR), collected on May 2, $1997 \ldots \ldots \ldots \ldots \ldots \ldots \ldots \ldots$

9. BE-1571 (MW-1-R), collected on May 7, $1997 \ldots \ldots \ldots \ldots \ldots \ldots$

10. BE-1583 (Wetzel), collected on May 6, $1997 \ldots \ldots \ldots \ldots \ldots \ldots \ldots \ldots$

11. BE-1584 (92-17), collected on May 8, $1997 \ldots \ldots \ldots \ldots \ldots \ldots \ldots \ldots . \ldots \ldots$

\section{TABLES}

Table 1. Boreholes logged at Crossley Farms Superfund Site, Berks County, Pennsylvania . . . . 4

2. Well depth, casing length, and depth to water for boreholes logged by the U.S. Geological Survey at Crossley Farms Superfund Site, Berks County, Pennsylvania ...............................

3-8. Summary of heat-pulse-flowmeter measurements for boreholes at Crossley Farms Superfund Site, Berks County, Pennsylvania:

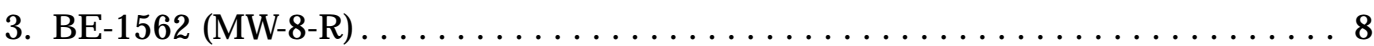

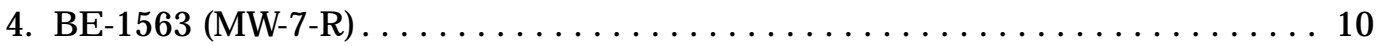

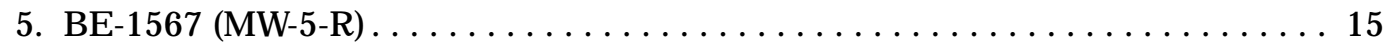

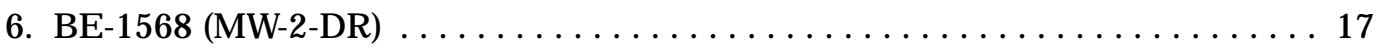

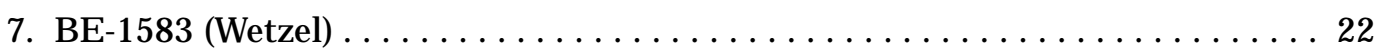

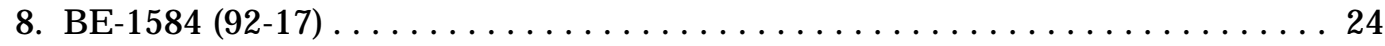




\section{CONVERSION FACTORS, ABBREVIATED WATER-QUALITY UNITS, AND VERTICAL DATUM}

$\begin{array}{lcl} & \text { Length } & \\ \text { inch (in.) } & 25.40 & \text { millimeter } \\ \text { foot (ft) } & 0.3048 & \text { meter } \\ \text { mile (mi) } & 1.609 & \text { kilometer } \\ & \text { Volume } & \\ \text { gallon per minute (gal/min) } & 0.00006309 & \text { cubic meter per second }\end{array}$

Abbreviated water-quality unit used in report:

$\mu \mathrm{g} / \mathrm{L}$, micrograms per liter

Sea level: In this report, "sea level" refers to the National Geodetic Vertical Datum of 1929-a geodetic datum derived from a general adjustment of the first-order level nets of the U nited States and Canada, formerly called Sea Level Datum of 1929. 



\title{
Evaluation of Geophysical Logs, Phase I, for Crossley Farms Superfund Site, Berks County, Pennsylvania
}

\author{
by Randall W. Conger
}

\begin{abstract}
Twenty-one wells were drilled at Crossley Farms Superfund Site between December 15, 1987, and May 1, 1988, to define and monitor the horizontal and vertical distribution of ground-water contamination emanating from a suspected contaminant source area (Blackhead Hill). Eight well clusters were drilled on or near the Crossley Site and three well clusters were drilled at locations hydrologically down gradient from the site. Depths of wells range from 21 to 299 feet bel ow land surface. These wells were installed in saprolite in shallow, intermediate, and deep water-producing zones of the fractured bedrock aquifer.

Borehole-geophysical and video logging were conducted between April 24, 1997, and May 8, 1997, to determine the water-producing zones, water-receiving zones, zones of vertical flow, borehole depth, and casing integrity in each well. This data and interpretation will be used to determine the location of the well intake for the existing open-hole wells, which will be retrofitted to isolate and monitor water-producing zones and prevent further cross-contamination within each open borehole, and identify wells that may need rehabilitation or replacement.

Caliper and video logs were used to locate fractures, inflections on fluid-temperature and fluidresistivity logs indicated possible fluid-bearing fractures, and flowmeter measurements verified these locations. Single-point-resistance and natural-gamma logs provided information on stratigraphy. After interpretation of geophysical logs, video logs, and driller's notes, all wells will be constructed so that water-level fluctuations can be monitored and discrete water samples collected from shallow, intermediate, and deep water-bearing zones in each well.

Geophysical logs were run on seven bedrock and two deep bedrock wells. Gamma logs were run on 10 bedrock wells. Twenty-two wells were inspected visually with the borehole video camera for casing integrity.
\end{abstract}




\section{INTRODUCTION}

The Crossley Farms Superfund Site is about 20 mi northeast of Reading, in the community of Huffs Church in Hereford Township, Berks County, Pa. (fig. 1). The Crossley Site boundaries are not delineated but are assumed to be the extent of the ground-water contamination plume previously documented near Blackhead Hill (Halliburton NUS, 1995).

At the Crossley Farms Superfund Site, illegal wastes were reported to be disposed of at the abandoned quartzite quarry and nearby areas on the top of Blackhead Hill during the mid-1960's to the mid-1970's (Halliburton NUS, 1995). In the early 1980's, nearby residents complained about the quality of their well water. In 1983, ground-water samples collected by the Pennsylvania Department of Environmental Resources and Roy F. Weston, Inc. indicated some residential wells were contaminated with trichloroethylene (TCE) and lesser concentrations of tetrachloroethene (PCE). Additional sampling identified TCE as the principal contaminant at concentrations as great as $22,857 \mu \mathrm{g} / \mathrm{L}$ in residential well water. Nearby affected residential wells are currently (1996) equipped with carbon filters at the point of use.

In 1987-88, a hydrogeologic assessment was conducted at the Crossley Farms Superfund Site by Roy F. Weston, Inc. and IT Corporation (Roy F. Weston/IT, 1988). They conducted soil gas surveys, drilled 21 monitor wells in proximity to the site, and concluded the source of the TCE was from the top of Blackhead Hill, probably near the abandoned quarry and borrow-pit area (Halliburton NUS, 1995). To delineate the extent of ground-water contamination, a Focused F easibility Study (FFS) and Remedial Investigation/F easibility Study (RI/FS) currently are being conducted by Brown and Root Environmental (B\&R), formerly Halliburton NUS Inc., to better characterize the nature and extent of hazardous contamination and evaluate remedial options for the contaminated residential wells.

This report evaluates borehole-geophysical and video logs run by the U.S. Geological Survey (USGS) in 21 boreholes at Crossley Farms Superfund Site, 1 private well adjacent to the site, and 1 well in downtown Bally (table 1, fig. 1). This report identifies one or more fluid-bearing zones in each borehole and describes problems with the integrity of the casing on the basis of geophysical and video-log data. Borehole video logs were run in all boreholes. Caliper, natural-gamma, single-pointresistance, fluid-resistivity, fluid-temperature, and borehole-flow (heat-pulse-flowmeter) logs were run in seven boreholes. Caliper, borehole video, natural-gamma, single-point-resistance, fluidresistivity, and fluid-temperature logs were run in one borehole. A natural-gamma log was run in three boreholes. A cross reference between USGS borehole-identification numbers and $B \& R$ borehole-identification numbers and a list of logs run in each borehole are shown in table 1. 


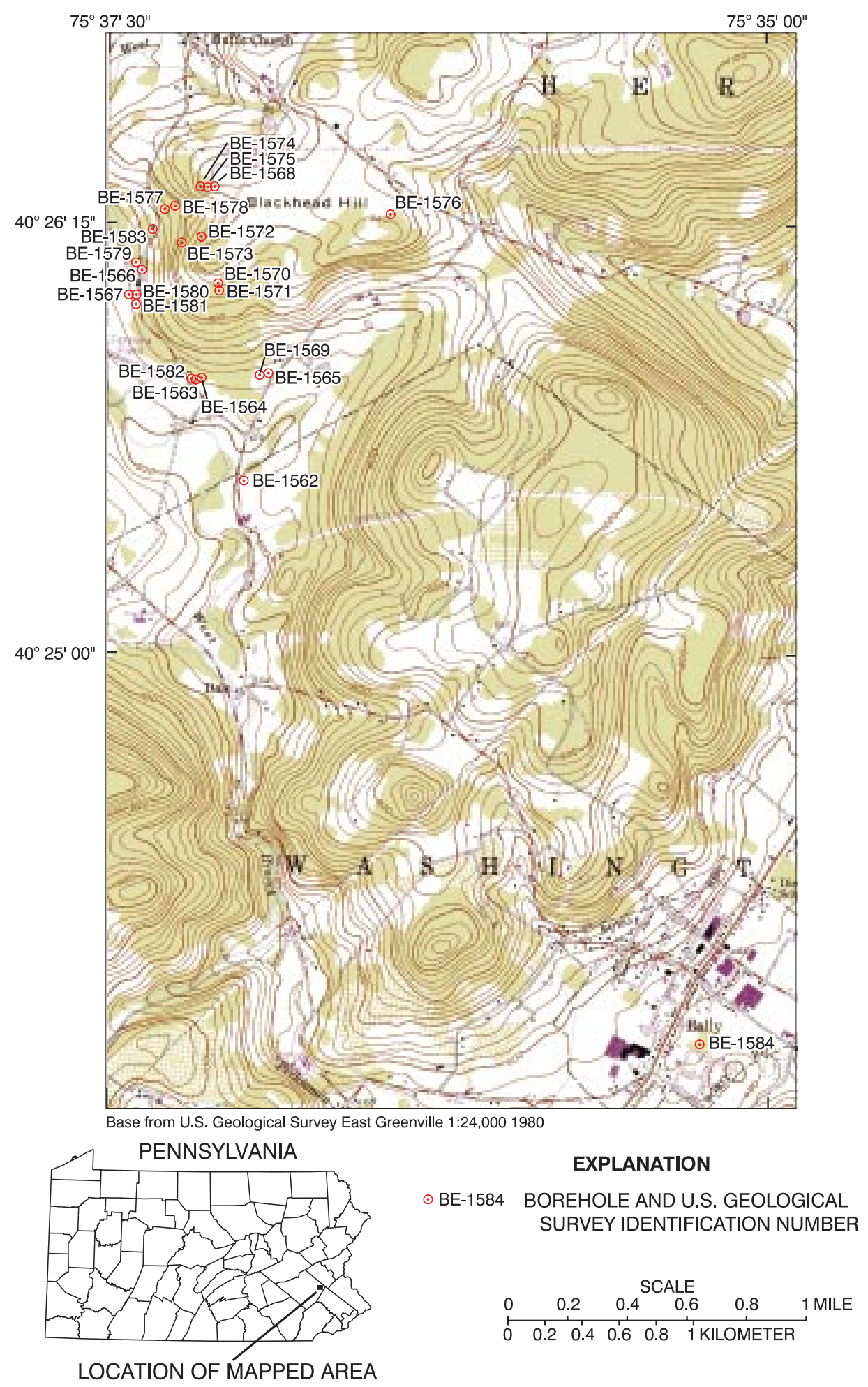

Figure 1. Locations of boreholes logged at the Crossley Farms Superfund Site, Berks County, Pennsylvania. 
Table 1. Boreholes logged at Crossley Farms Superfund Site, Berks County, Pennsylvania

[B, borehole-video log; C, caliper log; G, natural-gamma log; $R$, single-point-resistance log; $F$, fluid-resistivity log;

T, fluid-temperature log; V, borehole-flow measurement]

\begin{tabular}{|c|c|c|c|}
\hline $\begin{array}{c}\text { U.S. Geological } \\
\text { Survey borehole- } \\
\text { identification } \\
\text { number }\end{array}$ & $\begin{array}{c}\text { Brown and Root } \\
\text { Environmental } \\
\text { identification } \\
\text { number }\end{array}$ & $\begin{array}{l}\text { Depth logged } \\
\text { (feet) }\end{array}$ & $\begin{array}{c}\text { Geophysical logs } \\
\text { run }\end{array}$ \\
\hline BE-1562 & MW-8-R & 121 & $\mathrm{~B}, \mathrm{C}, \mathrm{G}, \mathrm{R}, \mathrm{F}, \mathrm{T}, \mathrm{V}$ \\
\hline BE-1563 & MW-7-R & 94 & $\mathrm{~B}, \mathrm{C}, \mathrm{G}, \mathrm{R}, \mathrm{F}, \mathrm{T}, \mathrm{V}$ \\
\hline BE-1564 & MW-7-DR & 122 & $\mathrm{~B}, \mathrm{C}, \mathrm{G}, \mathrm{R}, \mathrm{F}, \mathrm{T}$ \\
\hline BE-1565 & MW-6-R & 94 & $B, G$ \\
\hline BE-1566 & MW-4-R & 233 & $B, G$ \\
\hline BE-1567 & MW-5-R & 299 & $\mathrm{~B}, \mathrm{C}, \mathrm{G}, \mathrm{R}, \mathrm{F}, \mathrm{T}, \mathrm{V}$ \\
\hline BE-1568 & MW-2-DR & 302 & $\mathrm{~B}, \mathrm{C}, \mathrm{G}, \mathrm{R}, \mathrm{F}, \mathrm{T}, \mathrm{V}$ \\
\hline BE-1569 & MW-6-OB & 37 & B \\
\hline BE-1570 & MW-1-OB & 56 & B \\
\hline BE-1571 & MW-1-R & 162 & $\mathrm{~B}, \mathrm{G}$ \\
\hline BE-1572 & MW-1.1-OB & 41 & B \\
\hline BE-1573 & MW-1.2-OB & 44 & B \\
\hline BE-1574 & MW-2-OB & 26 & B \\
\hline BE-1575 & MW-2-R & 50 & B \\
\hline BE-1576 & MW-2.1-OB & 60 & B \\
\hline BE-1577 & MW-3-OB & 23 & B \\
\hline BE-1578 & MW-3-DOB & 69 & B \\
\hline BE-1579 & MW-4-OB & 21 & B \\
\hline BE-1580 & MW-5-OB & 33 & B \\
\hline BE-1581 & MW-5-DOB & 100 & B \\
\hline BE-1582 & MW-7-OB & 58 & B \\
\hline BE-1583 & Wetzel & 278 & $\mathrm{~B}, \mathrm{C}, \mathrm{G}, \mathrm{R}, \mathrm{F}, \mathrm{T}, \mathrm{V}$ \\
\hline BE-1584 & $92-17$ & 435 & $\mathrm{~B}, \mathrm{C}, \mathrm{G}, \mathrm{R}, \mathrm{F}, \mathrm{T}, \mathrm{V}$ \\
\hline
\end{tabular}




\section{Location and Physiography of Site}

The Crossley Farms Superfund Site is located in the Reading Prong Section of the New England Physiographic Province. The upland area of Blackhead Hill is underlain by Precambrian gneiss and Cambrian quartzite of the Hardystown Formation. The adjacent valley to the south and west is underlain mainly by Cambro-Ordovician dolomite of the Leithsville Formation. Bedrock is overlain by 30 to $120 \mathrm{ft}$ of unconsolidated regolith (Roy F. Weston/IT, 1988).

Ground water moves through the pore spaces of the regolith and fractures in the bedrock. Within the Leithsville F ormation, the fractures have been enlarged because of dissolution and weathering of the dolomite. Maps of the water table in the regolith indicate shallow ground water probably moves radially to the south and west from the summit of Blackhead Hill. Maps of the water table in the bedrock indicate a potential for ground-water movement from the quarry area to the south and west (Roy F. Weston/IT 1988). Within the Leithsville F ormation, hydraulic gradients are much less steep than in the crystalline bedrock. Ground water apparently moves from Blackhead Hill toward the valley; however, specific flow paths of ground water are difficult to characterize because they can be affected greatly by the anisotropy of the fractured bedrock and heterogeneity of water-bearing zones.

\section{Borehole-Geophysical Logs}

Geophysical logs provide information on location of fractures and water-bearing and waterreceiving zones (caliper and video log), intervals of vertical borehole flow (fluid-resistivity and fluidtemperature logs), quantification of borehole flow (heat-pulse flowmeter logs), lithologic correlation (gamma and electric logs), and data on well construction (caliper and electric logs) where unknown.

Caliper logs provide a continuous record of average borehole diameter, which is related to fractures, lithology, and drilling technique. Caliper logs are used to identify fractures and possible water-producing openings and to correct other geophysical logs for changes in borehole diameter. Correlation of caliper logs with fluid-resistivity and fluid-temperature logs is used to identify fractures, water-producing zones, and water-receiving zones and to measure water velocity.

The natural-gamma or gamma log measures the natural-gamma radiation (photons) emitted from all rocks. The most common sources of gamma radiation are uranium-238, thorium-232, their daughter elements, and potassium-40. These radioactive elements are concentrated in clays by adsorption, precipitation, and ion exchange. Fine-grained sediments such as shale or siltstone usually emit more gamma radiation than sandstone, limestone, or dolomite. The gamma log can be run in or out of water or casing. However, casing does reduce the gamma response. The gamma log is used to correlate geologic units between wells (Keys, 1988).

The single-point-resistance log measures the electrical resistance of a formation between the probe in a water-filled borehole bel ow casing and an electrical ground at land surface. Generally, electrical resistance increases with formation grain size and decreases with increasing borehole diameter, water-bearing fractures, and increasing dissolved-solids concentration of borehole fluid. The single-point-resistance log is used to correlate geology between wells and may help identify formation water-bearing zones. (Keys and MacCary, 1971).

Fluid resistivity is the inverse of fluid conductivity. The fluid-resistivity log measures the electrical resistivity of the water column in the well. The fluid-resistivity probe measures the resistivity of borehole water between el ectrodes in the probe. Fluid-resistivity logs reflect changes in the dissolved-solids concentration of the well water. Fluid-resistivity logs are used to identify waterproducing and water-receiving zones and to determine intervals of vertical borehole flow. Waterproducing and water-receiving zones are usually identified by distinct changes in resistivity. Intervals of vertical borehole flow are usually identified by a low-resistivity gradient between a water-producing and a water-receiving zone. Also, zones of salt-water intrusion and some types of contaminant plumes can be identified. 
Fluid-temperature logs provide a continuous record of the vertical variation in temperature of the water in a borehole. Temperature logs are used to identify water-producing and water-receiving zones and to determine zones of vertical borehole flow. Intervals of vertical borehole flow are characterized by little or no temperature gradient (Williams and Conger, 1990).

The direction and rate of any movement of water in the borehole was determined by the use of a heat-pulse flowmeter. The heat-pulse flowmeter operates by heating a small sheet of water between two sensitive thermistors (heat sensors). A measurement of direction and rate is computed when a peak temperature is recorded by one of the thermistors. The range of flow measurement is about 0.01-1.5 gal/min in a 2- to 10-in.-diameter borehole (Conger, 1996).

All flow measurements were conducted under ambient conditions. The flowmeter can measure flow only if pressure head differences exist between water-producing zones in the borehole.

Some heat-pulse-flowmeter measurements may be influenced by (1) an incomplete seal between the borehole and heat-pulse flowmeter and (2) contributions of water from storage within the borehole. If the seal between the borehole and flowmeter is not complete, some water can bypass the flowmeter, resulting in flow measurements that are less than the actual rate. When flowmeter measurements are conducted under pumping conditions, some measurements of flow rate may be affected if the water level in the borehole has not stabilized. When drawdown has not completely stabilized, a portion of the discharge water is contributed from storage within the borehole rather than from the aquifer. Although the heat-pulse flowmeter is a calibrated probe, the data are used primarily as a relative indicator to identify water-producing and water-receiving zones.

Borehole television logging was conducted by lowering a waterproof video camera down the borehole and recording the image on video tape. The depth indicated on the video log may not correspond exactly to the geophysical logs because of some minor slippage of the television cable. 


\section{EVALUATION OF BOREHOLE-GEOPHYSICAL LOGS}

The locations of boreholes logged are shown on figure 1. The reference measuring point for all geophysical and video logs is land surface. Depth of wells, casing lengths, and water levels at the time of logging are given in feet below land surface (table 2).

Table 2. Well depth, casing length, and depth to water for boreholes logged by the U.S. Geological Survey at Crossley Farms Superfund Site, Berks County, Pennsylvania

[ft, feet]

\begin{tabular}{|c|c|c|c|c|c|}
\hline $\begin{array}{l}\text { U.S. Geological } \\
\text { Survey borehole- } \\
\text { identification } \\
\text { number }\end{array}$ & $\begin{array}{l}\text { Depth of well } \\
\text { below land } \\
\text { surface } \\
(\mathrm{ft})\end{array}$ & $\begin{array}{l}\text { Length of casing } \\
\text { and screen } \\
\text { below land } \\
\text { surface } \\
\text { (ft) }\end{array}$ & $\begin{array}{c}\text { Open }(\mathrm{O}) \text { or } \\
\text { screened (S) } \\
\text { interval below } \\
\text { land surface } \\
(\mathrm{ft})\end{array}$ & $\begin{array}{l}\text { Depth to water } \\
\text { below } \\
\text { land surface } \\
\text { (ft) }\end{array}$ & $\begin{array}{c}\text { Date } \\
\text { water level } \\
\text { measured }\end{array}$ \\
\hline BE-1562 & 121 & 76 & $76-121(0)$ & 13.07 & $4 / 24 / 97$ \\
\hline BE -1563 & 94 & 58 & $58-94(0)$ & 47.50 & $4 / 25 / 97$ \\
\hline BE-1564 & 122 & 108 & $108-122(0)$ & 47.76 & $4 / 25 / 97$ \\
\hline BE-1565 & 94 & 94 & collapsed & 49.33 & $4 / 25 / 97$ \\
\hline BE-1566 & 232 & 228 & $228-233(0)$ & 57.05 & $4 / 25 / 97$ \\
\hline BE-1567 & 299 & 196 & 196-299 (O) & 33.91 & $4 / 25 / 97$ \\
\hline BE-1568 & 302 & 56 & $56-302(0)$ & 24.07 & $5 / 2 / 97$ \\
\hline BE-1569 & 37 & 37 & 29-37 (S) & 20.8 & $5 / 2 / 97$ \\
\hline BE-1570 & 56 & 56 & $46-56(S)$ & 20.0 & $5 / 8 / 97$ \\
\hline BE-1571 & 162 & undetermined $^{1}$ & & 27.15 & $5 / 7 / 97$ \\
\hline BE-1572 & 41 & 41 & $31-41(S)$ & 31.9 & $5 / 8 / 97$ \\
\hline BE -1573 & 44 & 44 & $34-44$ (S) & 39.3 & $5 / 8 / 97$ \\
\hline BE-1574 & 26 & 26 & $16-26(S)$ & dry & $5 / 6 / 97$ \\
\hline BE-1575 & 50 & undetermined $^{1}$ & & 26.5 & $5 / 6 / 97$ \\
\hline BE-1576 & 60 & 60 & $50-60(S)$ & 40.3 & $5 / 8 / 97$ \\
\hline BE-1577 & 23 & 23 & $13-23(\mathrm{~S})$ & .5 & $5 / 6 / 97$ \\
\hline BE-1578 & 69 & 69 & $49-69$ (S) & 30.2 & $5 / 6 / 97$ \\
\hline BE-1579 & 21 & 21 & $11-21(\mathrm{~S})$ & 1.7 & $5 / 6 / 97$ \\
\hline BE-1580 & 33 & 33 & $23-33(\mathrm{~S})$ & 24.1 & $5 / 8 / 97$ \\
\hline BE-1581 & 100 & 100 & $82-100(S)$ & 55.1 & $5 / 8 / 97$ \\
\hline BE-1582 & 58 & 58 & $38-58$ (S) & 49.2 & $5 / 6 / 97$ \\
\hline BE-1583 & 278 & 256 & $56-278(0)$ & 31.98 & $5 / 6 / 97$ \\
\hline BE-1584 & 435 & 54 & $54-435(0)$ & 3.64 & $5 / 8 / 97$ \\
\hline
\end{tabular}

1 Unable to determine visually; water cloudy.

${ }^{2}$ Apparent casing depth. 


\section{BE-1562 (MW-8-R)}

The caliper log shows the total depth of the borehole is $121 \mathrm{ft}$ and it is cased with 6-in.-diameter casing (fig. 2). The static water level was $13.07 \mathrm{ft}$ bls (bel ow land surface). The single-pointresistance log shows steel casing to $76 \mathrm{ft}$ bls. The caliper log shows major fractures at 98-102 and 118-121 ft bls and several minor fractures throughout the open-hole interval. The fluid-resistivity log shows a change in slope at approximately $76 \mathrm{ft}$ bls that correlates to a minor fracture shown on the caliper log. The video log shows the borehole water becomes slightly cloudy bel ow casing, more cloudy at $91 \mathrm{ft}$ bls, then visibility declines to zero near the bottom of the borehole. Under ambient conditions, the heat-pulse flowmeter measured upward borehole flow at 86, 96, and $108.5 \mathrm{ft}$ bls (table 3). The geophysical logs and the heat-pulse-flowmeter data indicate water enters the borehole through the large fracture at 118-121 ft bls, moves upward, and exits the borehole through a small fracture near the bottom of casing at $76 \mathrm{ft}$ bls. If the water produced at the fracture at 118-121 ft bls is contaminated, leaving this well as an open borehole may cross-contaminate the water-receiving zone. A screen and sand placed at $111-121 \mathrm{ft}$ bls would include the water-producing fractures at 118-121 ft bls.

Table 3. Summary of heat-pulse-flowmeter measurements for borehole BE-1562 (MW-8-R) at Crossley Farms Superfund Site, Berks County, Pennsylvania

[ft bls, feet below land surface; gal/min, gallons per minute]

\begin{tabular}{ccc}
\hline $\begin{array}{c}\text { Depth } \\
\text { (ft bls) }\end{array}$ & $\begin{array}{c}\text { Flow rate under } \\
\text { ambient } \\
\text { conditions } \\
\text { (gal/min) }\end{array}$ & $\begin{array}{c}\text { Flow direction } \\
\text { under ambient } \\
\text { conditions }\end{array}$ \\
\hline 70 & no flow & \\
86 & 0.20 & up \\
96 & .24 & up \\
108.5 & .27 & up \\
\hline
\end{tabular}



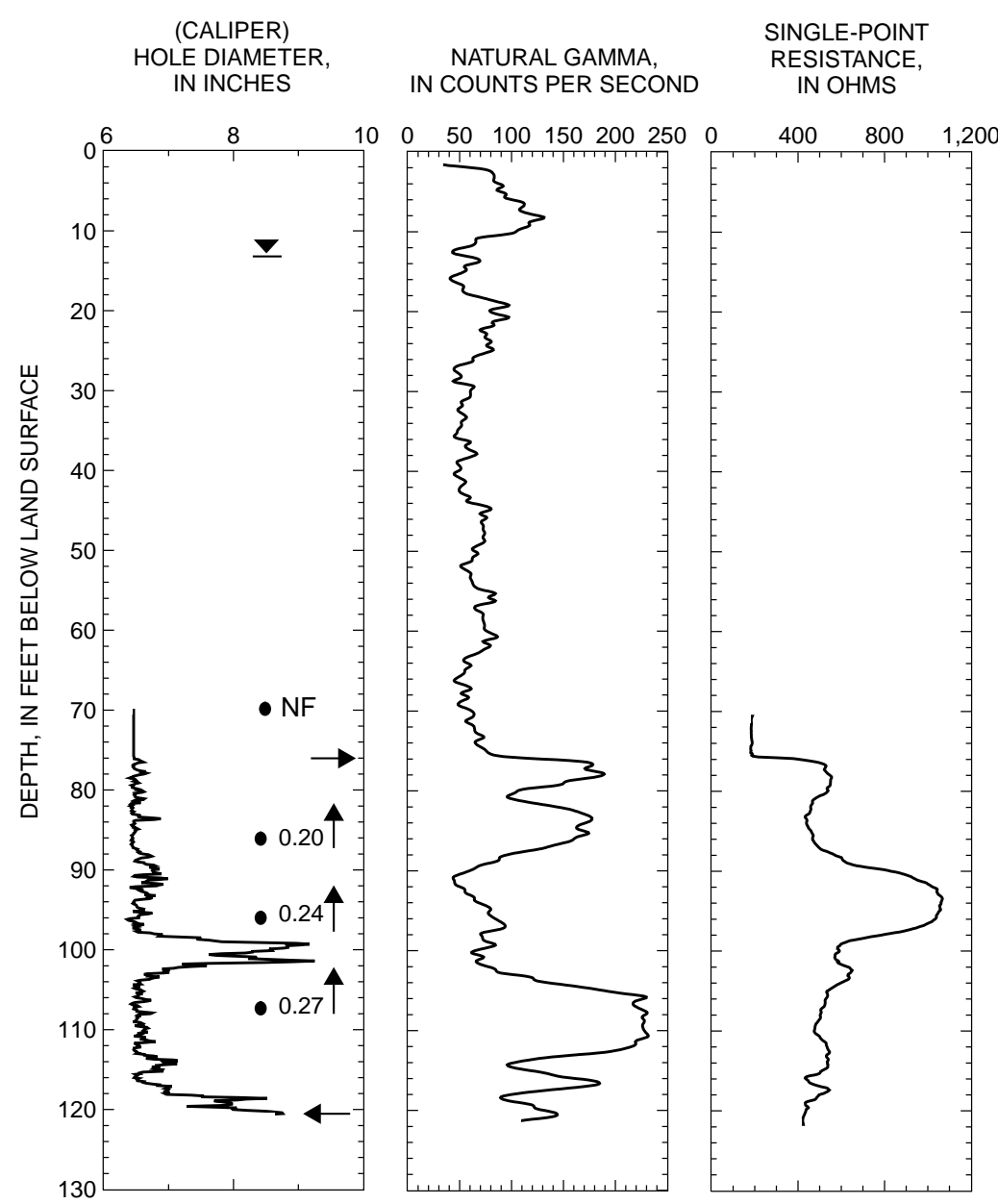
FLUID RESISTIVITY,
IN OHM-METERS

FLUID TEMPERATURE, IN COUNTS PER SECOND IN OHMS
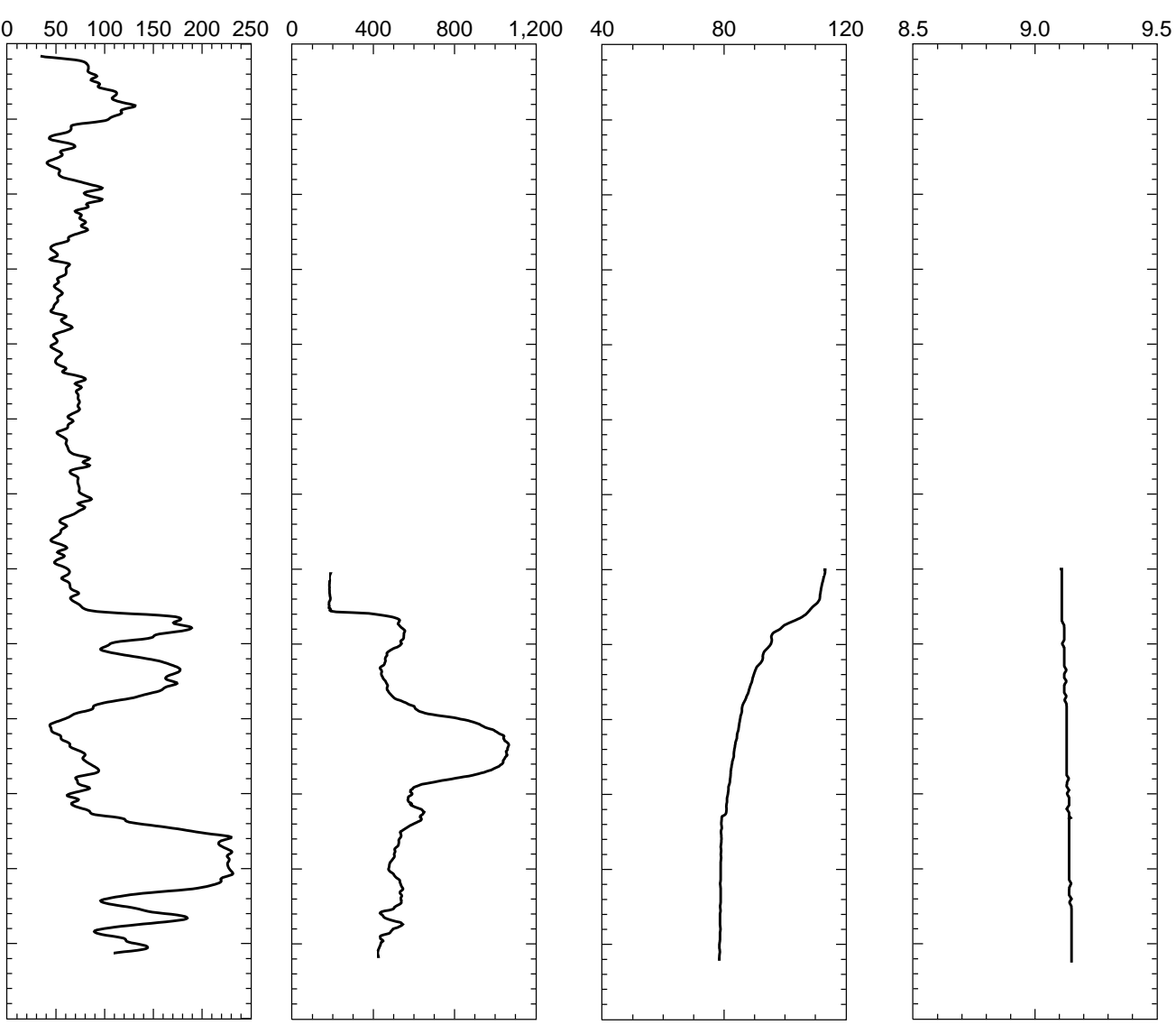

EXPLANATION

₹ STATIC WATER LEVEL

NF NO FLOW

$\longleftarrow$ FLOW INTO BOREHOLE

$\rightarrow$ FLOW OUT OF BOREHOLE $\downarrow \uparrow \underset{\text { FLOW }}{\text { UP OR DOWN BOREHOLE }}$

- 0.20 BOREHOLE-FLOW MEASUREMENTCircle at depth of flow measurement.

Number is measured

flow in gallons per minute.

Figure 2. Borehole-geophysical logs for borehole BE-1562 (MW-8-R), collected on April 24, 1997, Crossley Farms Superfund Site, Berks County, Pennsylvania. 


\section{BE-1563 (MW-7-R)}

The caliper log shows the total depth of the borehole is $94 \mathrm{ft}$ and it is cased with 6.25-in.diameter casing (fig. 3). The static water level was $47.50 \mathrm{ft}$ bls. The single-point-resistance log shows steel casing to $58 \mathrm{ft}$ bls. The caliper log shows a fracture at $93 \mathrm{ft}$ bls and only minor fractures throughout the open-hole interval. The fluid-resistivity log shows a change in slope at $58-60 \mathrm{ft}$ bls that correlates to minor fractures on the caliper log. The video log shows the bor ehole water becomes slightly cloudy near the bottom of casing. Under ambient conditions, the heat-pulse-flowmeter data indicated upward borehole flow at 50, 56, 66, 74, and $84 \mathrm{ft}$ bls (table 4). The geophysical logs and the heat-pulse-flowmeter data indicate water enters the borehole through the fracture at $93 \mathrm{ft}$ bls, moves upward, and exits the borehole through a break in casing above $50 \mathrm{ft}$ bls. If the water produced by the fracture at $93 \mathrm{ft}$ bls is contaminated, leaving this well as an unrepaired open borehole may crosscontaminate the shallow water-producing zones. Screen and sand placed at 84-94 ft bls would include the water-producing zone at $93 \mathrm{ft}$ bls.

Table 4. Summary of heat-pulse-flowmeter measurements for borehole BE-1563 (MW-7-R) at Crossley Farms Superfund Site, Berks County, Pennsylvania

[ft bls, feet below land surface; gal/min, gallons per minute]

\begin{tabular}{ccc}
\hline Depth (ft bls) & $\begin{array}{c}\text { Flow rate } \\
\text { under ambient } \\
\text { conditions } \\
\text { (gal/min) }\end{array}$ & $\begin{array}{c}\text { Flow direction } \\
\text { under ambient } \\
\text { conditions }\end{array}$ \\
\hline 50 & 0.15 & up \\
56 & .13 & up \\
66 & .13 & up \\
74 & .09 & up \\
84 & .11 & up \\
\hline
\end{tabular}




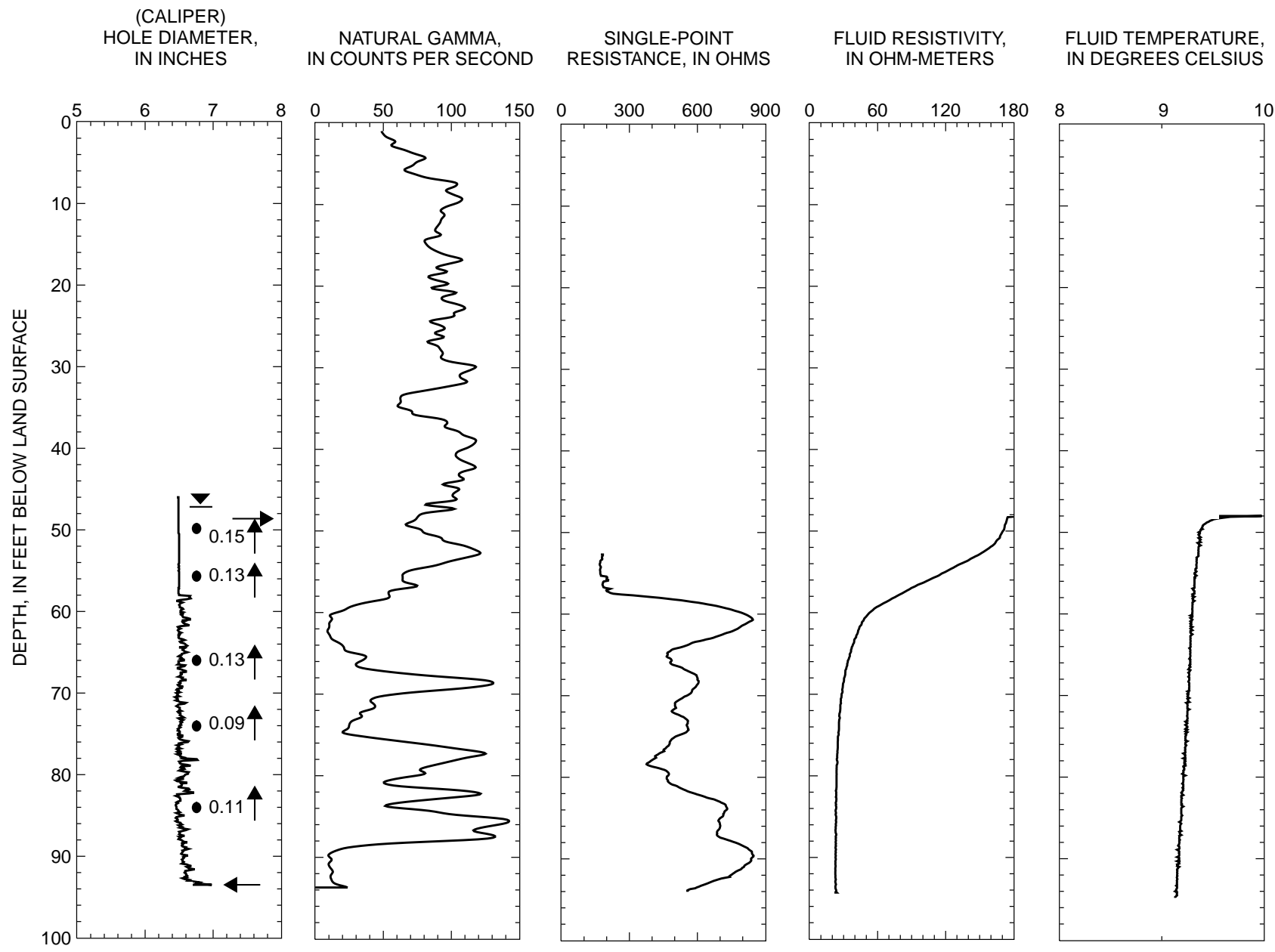

\section{EXPLANATION \\ $\checkmark$ STATIC WATER LEVEL \\ $\longleftarrow$ FLOW INTO BOREHOLE \\ $\rightarrow$ FLOW OUT OF BOREHOLE \\ L个 UP OR DOWN BOREHOLE FLOW}

- 0.15 BOREHOLE-FLOW MEASUREMENT-

Circle at depth of

flow measurement.

Number is measured

flow in gallons per minute.

Figure 3. Borehole-geophysical logs for borehole BE-1563 (MW-7-R), collected on April 25, 1997, Crossley Farms Superfund Site Berks County, Pennsylvania. 


\section{BE-1564 (MW-7-DR)}

The caliper log shows the total depth of the borehole is $122 \mathrm{ft}$ and it is cased with 6.25-in.diameter casing (fig. 4). The static water level was $47.76 \mathrm{ft}$ bls. The single-point-resistance log shows steel casing extends to $108 \mathrm{ft}$ bls. The caliper log shows a major fracture at $115 \mathrm{ft}$ bls. The singlepoint-resistance log shows a spike at $115 \mathrm{ft}$ bls that correlates to a fracture shown on the caliper log, which indicates a water-producing zone. The video log shows the borehole water becoming slightly cloudy in the open hole and a large horizontal fracture at $115 \mathrm{ft}$ bls. A screen placed at 110-120 ft bls would include the apparent water-producing zone at $115 \mathrm{ft}$ bls.

\section{BE-1565 (MW-6-R)}

Only the gamma and video logs were run in this borehole. The static water level was $49.33 \mathrm{ft}$ bls. The gamma log shows the total depth of the borehole is $94 \mathrm{ft}$ bls (fig. 5). The borehole video log shows the casing is in good condition and extends to at least $94 \mathrm{ft}$ bls. The borehole has completely collapsed bel ow the casing; no open hole exists.

\section{BE-1566 (MW-4-R)}

The gamma and video logs were run in this borehole. The static water level was $57.05 \mathrm{ft}$ bls. The gamma log shows the total depth of the borehole is $232 \mathrm{ft}$ bls and it is cased with steel to $228 \mathrm{ft}$ bls (fig. 6). The borehole-video log shows the casing is broken or cracked above a joint at $46 \mathrm{ft}$ bls. The video log identified fractures at $228-230 \mathrm{ft}$ bls and a large vertical fracture at $232 \mathrm{ft}$ bls. If water is produced by fractures near the break in casing at $46 \mathrm{ft}$ bls and is contaminated, leaving this well unrepaired may cross-contaminate water-receiving zones. A screen placed at 228-232 ft bls would include the current open-hole interval and restrict any vertical flow caused as a result of damaged casing. 


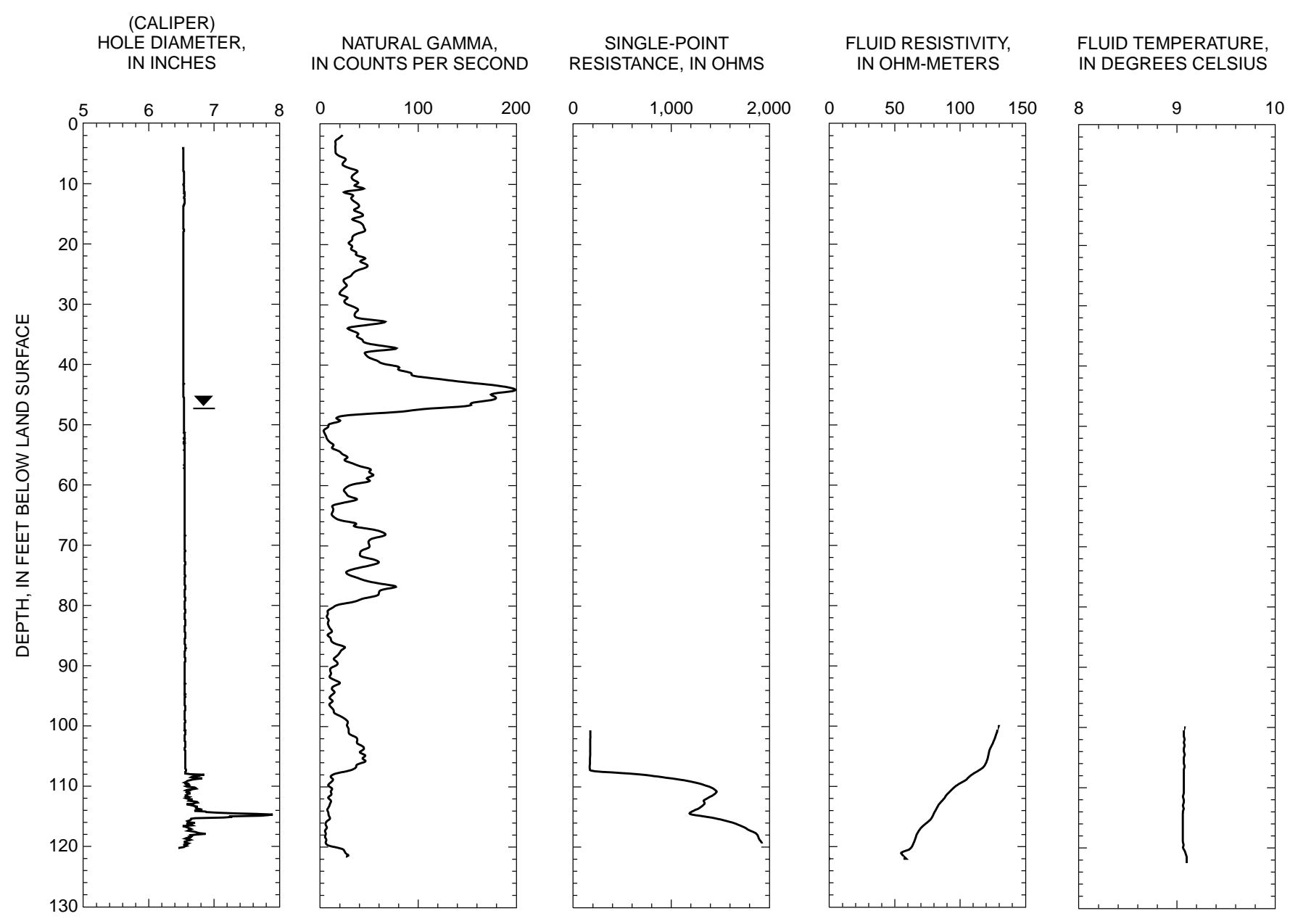

EXPLANATION

- STATIC WATER LEVEL

Figure 4. Borehole-geophysical logs for borehole BE-1564 (MW-7-DR), collected on April 25, 1997, Crossley Farms Superfund Site,

Berks County, Pennsylvania. 

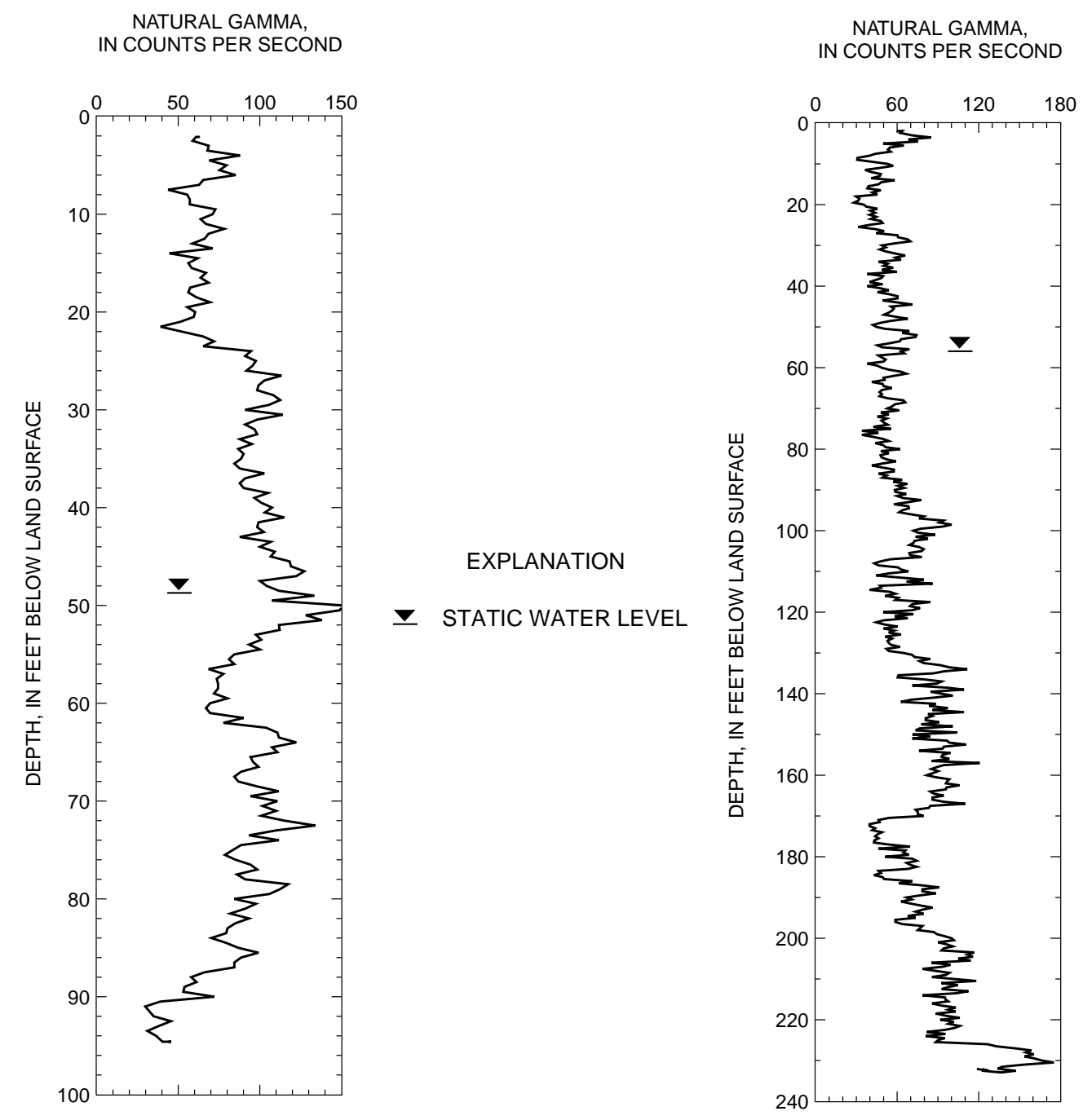

Figure 5. Borehole-geophysical log for borehole BE-1565 (MW-6-R), collected on April 25, 1997, Crossley Farms Superfund Site, Berks County, Pennsylvania.

Figure 6. Borehole-geophysical log for borehole BE-1566 (MW-4-R), collected on April 25, 1997, Crossley Farms Superfund Site, Berks County, Pennsylvania. 


\section{BE-1567 (MW-5-R)}

The caliper log shows the total depth of the borehole is $299 \mathrm{ft}$ and it is cased with 6-in.-diameter casing (fig. 7). The static water level was $33.91 \mathrm{ft}$ bls. The single-point-resistance log shows steel casing to $196 \mathrm{ft}$ bls. The caliper log shows fractures at $206 \mathrm{ft}$ bls and only minor fractures throughout the open-hole interval. The caliper log shows the bottom $9 \mathrm{ft}$ of the borehole is filled with soft sediment. The fluid-resistivity and fluid-temperature logs show a change in slope at $269 \mathrm{ft}$ bls that correlates to a minor fracture on the caliper log and may indicate a water-producing zone. The video log shows the visibility of the borehole water becomes zero bel ow $52 \mathrm{ft}$ bls. Under ambient conditions, the heat-pulse-flowmeter measurements indicated upward borehole flow at 199 and $220 \mathrm{ft}$ bls and no flow at 241 and $258 \mathrm{ft}$ bls (table 5). The geophysical logs and the heat-pulse-flowmeter data indicate water enters the borehole through the fractures between 222 and $238 \mathrm{ft}$ bls moves upward and exits the borehole through fractures at approximately $196 \mathrm{ft}$ bls. If the water produced by the fractures at 222-238 ft bls is contaminated, leaving this well as an open borehole may create cross-contamination of the deeper water-producing zones. A screen placed at 200-210 or 221-241 ft bls would include the water-receiving and water-producing zone at 204 or 222-238 ft bls, respectively.

Table 5. Summary of heat-pulse-flowmeter measurements for borehole BE-1567 (MW-5-R) at Crossley Farms Superfund Site, Berks County, Pennsylvania

[ft bls, feet below land surface; gal/min, gallons per minute]

\begin{tabular}{ccc}
\hline Depth (ft bls) & $\begin{array}{c}\text { Flow rate } \\
\text { under ambient } \\
\text { conditions } \\
\text { (gal/min) }\end{array}$ & $\begin{array}{c}\text { Flow direction } \\
\text { under ambient } \\
\text { conditions }\end{array}$ \\
\hline 190 & no flow & up \\
199 & 0.10 & up \\
220 & .20 & \\
241 & no flow & \\
258 & no flow & \\
\hline
\end{tabular}




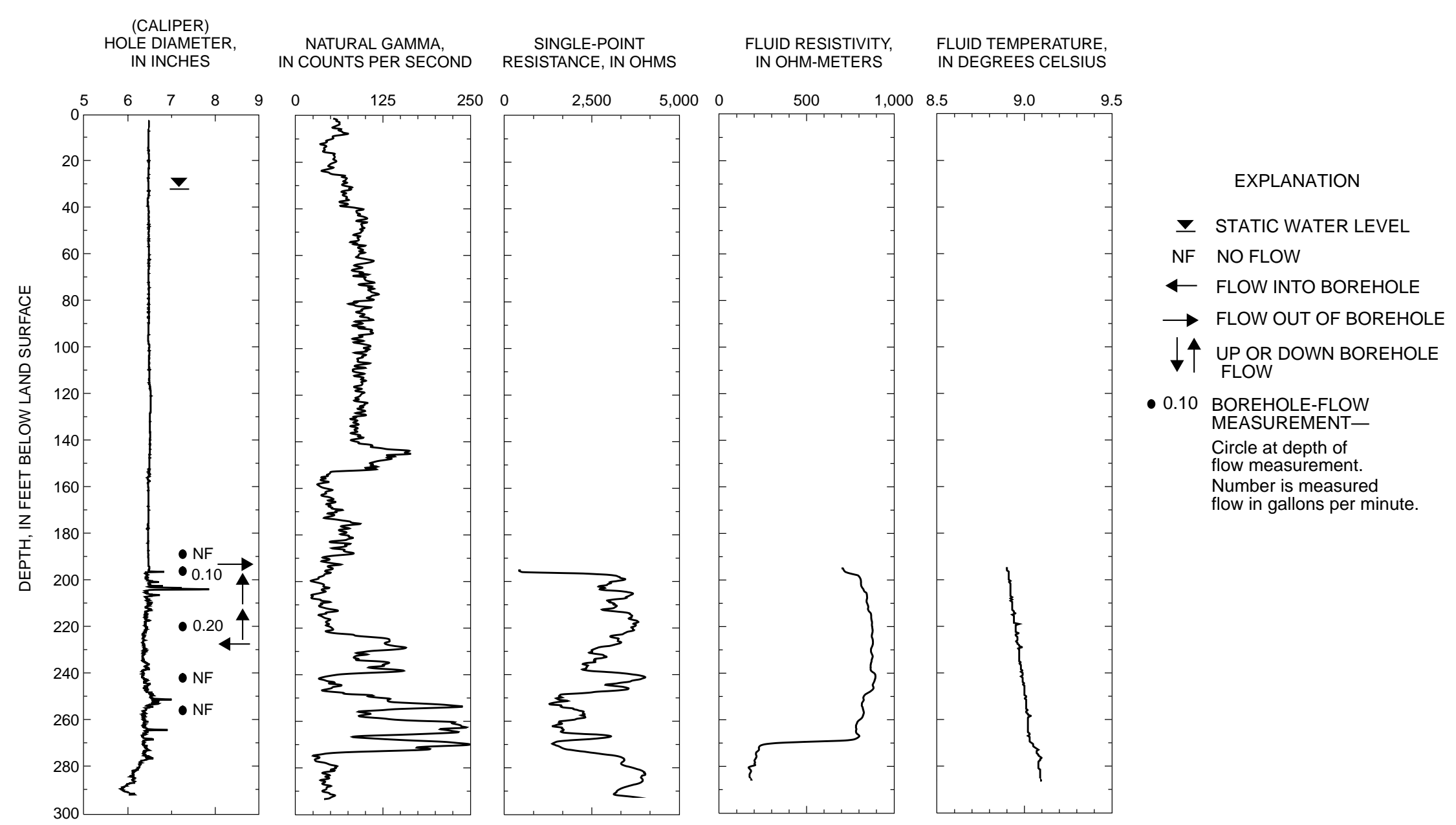

Figure 7. Borehole-geophysical logs for borehole BE-1567 (MW-5-R), collected on April 25, 1997, Crossley Farms Superfund Site, Berks County, Pennsylvania. 


\section{BE-1568 (MW-2-DR)}

The caliper log shows the total depth of the borehole is $302 \mathrm{ft}$ and it is cased with 6-in.-diameter casing (fig. 8). The static water level was $24.07 \mathrm{ft} \mathrm{bls.} \mathrm{The} \mathrm{single-point-resistance} \mathrm{log} \mathrm{shows} \mathrm{steel}$ casing to $56 \mathrm{ft}$ bls. The caliper log shows numerous minor fractures throughout the open-hole interval. The fluid-resistivity log shows a sudden change in slope at about $70 \mathrm{ft}$ bls that correlates to a minor fracture on the caliper log and may be indicative of lateral borehole flow. Under ambient conditions, the heat-pulse-flowmeter measurements indicate minor upward borehole flow at 250, 264, 282, and $294 \mathrm{ft}$ bls and no flow at 80, 128, and $216 \mathrm{ft}$ bls (table 6). The geophysical logs and the heat-pulse-flowmeter data indicate water enters the borehole through the fractures at 286 and $300 \mathrm{ft}$ bls, moves upward, and exits the borehole through fractures between 220 and $245 \mathrm{ft}$ bls. If the water produced by the fractures at 286 and $300 \mathrm{ft}$ bls is contaminated, leaving this well as an open bor ehole may create cross-contamination of the deeper water-producing zones. A screen placed at 220-245 ft bls or 250-300 ft bls would include the minor water-receiving and water-producing fractures, respectively, at these intervals.

Table 6. Summary of heat-pulse-flowmeter measurements for borehole BE-1568 (MW-2-DR) at Crossley Farms Superfund Site, Berks County, Pennsylvania

[ft bls, feet below land surface; gal/min, gallons per minute]

\begin{tabular}{ccc}
\hline Depth (ft bls) & $\begin{array}{c}\text { Flow rate } \\
\text { under ambient } \\
\text { conditions } \\
\text { (gal/min) }\end{array}$ & $\begin{array}{c}\text { Flow direction } \\
\text { under ambient } \\
\text { conditions }\end{array}$ \\
\hline 80 & no flow & \\
128 & no flow & \\
216 & no flow & \\
250 & 0.06 & up \\
264 & .05 & up \\
282 & .08 & up \\
294 & .05 & up \\
\hline
\end{tabular}

\section{BE-1569 (MW-6-OB)}

Only the borehole-video log was run in this well. The log shows the total depth of the borehole is $37 \mathrm{ft}$ bls and it is screened from 29 to at least $37 \mathrm{ft}$ bls. The static water level was $20.8 \mathrm{ft}$ bls. The PVC casing is broken and misaligned at $3 \mathrm{ft}$ bls and leaking bel ow a joint at $19.5 \mathrm{ft}$ bls. The video log shows silt on the bottom of the well.

\section{BE-1570 (MW-1-OB)}

Only the borehole-video log was run in this well. The log shows the total depth of the borehole is $56 \mathrm{ft}$ bls and it is screened with PVC from about 47 to $56 \mathrm{ft}$ bls. The static water level was $20.0 \mathrm{ft}$ bls. The video log shows dirty joints at 7.4, 17.4, and 36.7-46.7 ft bls, indicating locations of possible seepage into the well. The video log shows an apparent high water-level mark (stain) at $13.7 \mathrm{ft}$ bls, staining possibly from iron or bacteria at $48 \mathrm{ft}$ bls, and silt on the bottom at $56 \mathrm{ft}$ bls. 


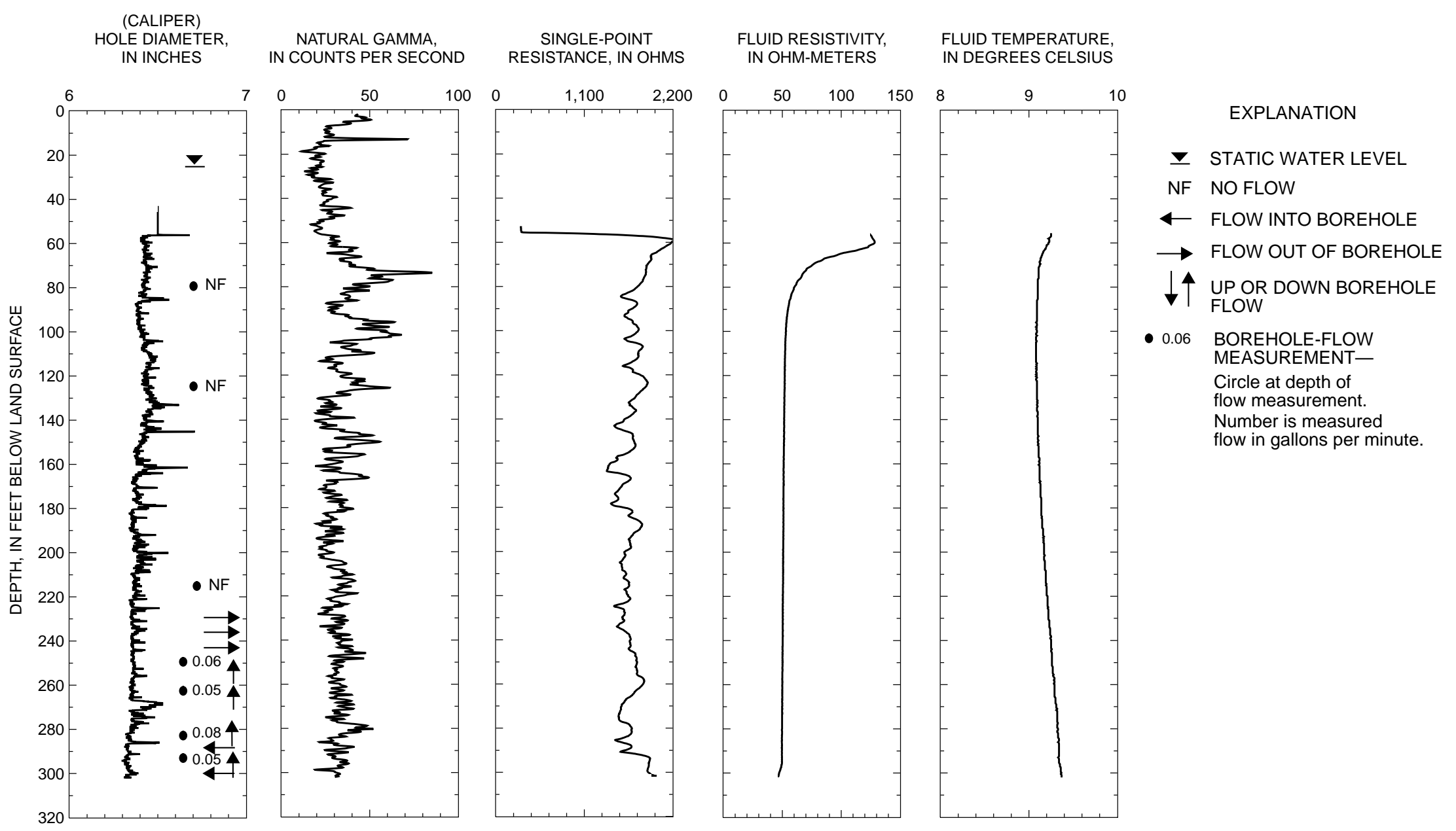

Figure 8. Borehole-geophysical logs for borehole BE-1568 (MW-2-DR), collected on May 2, 1997, Crossley Farms Superfund Site, Berks County, Pennsylvania. 


\section{BE-1571(MW-1-R)}

The gamma and borehole-video logs were run in this borehole. The gamma log shows the total depth of the borehole is $162 \mathrm{ft}$ bls (fig. 9). The static water level was $27.15 \mathrm{ft}$ bls. The video log could not define depth of casing because of poor visibility. The video log shows the water becomes cloudy bel ow $60 \mathrm{ft}$ bls, the borehole becomes visually out of plumb at $135 \mathrm{ft}$ bls, and visibility becomes very low at $150 \mathrm{ft}$ bls to bottom. This borehole is the most contaminated with volatile organic compounds (Halliburton, NUS, written commun., 1996).

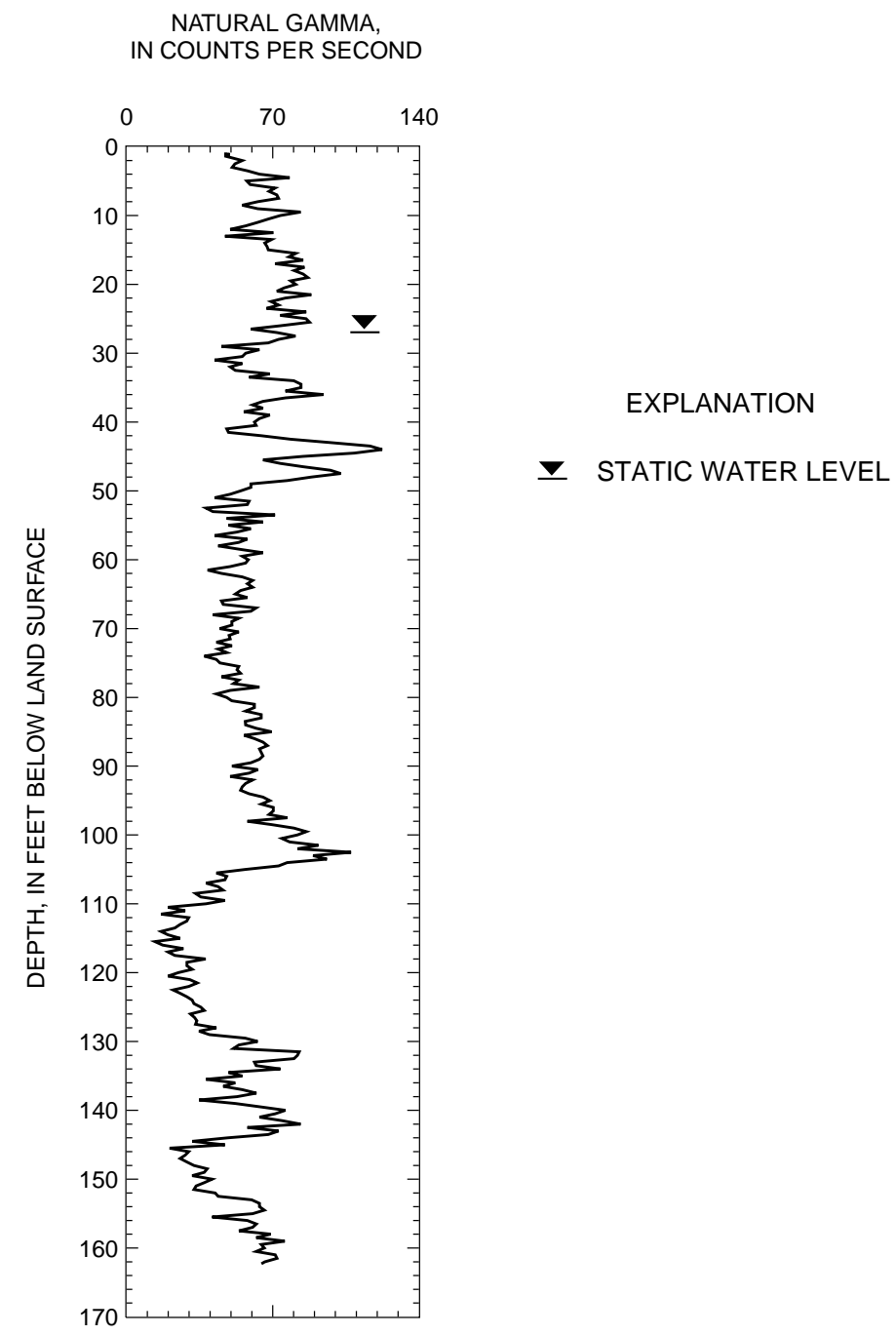

Figure 9. Borehole-geophysical log for borehole BE-1571 (MW-1-R), collected on May 7, 1997, Crossley Farms Superfund Site, Berks County, Pennsylvania. 


\section{BE-1572 (MW-1.1-OB)}

Only the borehole-video log was run in this well. The log shows the total depth of the well is $41 \mathrm{ft}$ bls and it is screened with PVC from 31 to $41 \mathrm{ft}$ bls. The static water level was $31.9 \mathrm{ft}$ bls. The video log shows light-colored staining at 11.7 and $25-27 \mathrm{ft}$ bls, indicating possible seepage into the well. PVC casing threads are visible at the top of the PVC screen at $30.8 \mathrm{ft}$ bls, indicating incomplete tightening of the casing joint.

\section{BE-1573 (MW-1.2-OB)}

Only the borehole-video log was run in this well. The log shows the total depth of the well is $44 \mathrm{ft}$ bls and it is screened from 34 to $44 \mathrm{ft}$ bls. The static water level was $39.3 \mathrm{ft}$ bls. The video log shows an apparent high water mark at $22.6 \mathrm{ft}$ bls and light-colored staining at 32.7 and $36 \mathrm{ft} \mathrm{bls,}$ indicating locations of possible seepage into the well. Some type of debris and staining are located just below water level at $39.3 \mathrm{ft}$ bls. PVC casing threads are visible at the top of the screen at $34 \mathrm{ft}$ bls, indicating incomplete tightening of the casing joint.

\section{BE-1574 (MW-2-OB)}

Only the borehole-video log was run in this borehole. The log shows the total depth of the well is $26 \mathrm{ft}$ bls and it is screened with PVC from 15.8 to $25.8 \mathrm{ft}$ bls. The borehole-video log shows the well has dry, brown stains at 13.5, 19.8, and $24.5 \mathrm{ft}$ bls (may indicate previous water levels), an undefined semicircle on the PVC screen at $20.5 \mathrm{ft}$ bls, and debris on well bottom.

\section{BE-1575 (MW-2-R)}

Only the borehole-video log was run in this well. The log shows the total depth of the borehole is $50 \mathrm{ft}$ bls. The static water level was $26.5 \mathrm{ft}$ bls. The video log could not define the depth of steel casing because of poor visibility. The borehole-video log shows large openings and horizontal fractures at 35 and $42 \mathrm{ft}$ bls. The borehole is partially constricted at $42 \mathrm{ft}$ bls because of shifting of loose formation material.

\section{BE-1576 (MW-2.1-OB)}

Only the borehole-video log was run in this well. The log shows the total depth is $60 \mathrm{ft}$ bls and it is screened with PVC casing from approximately 50 to $60 \mathrm{ft}$ bls. The static water level was $40.3 \mathrm{ft}$ bls. The video log shows stains at 33.4, 39.2, and $45 \mathrm{ft}$ bls that may indicate different static water levels. The screen is slightly stained and dirty.

\section{BE-1577 (MW-3-OB)}

Only the borehole-video log was run in this well. The log shows the total depth is $23 \mathrm{ft}$ bls and it is screened with PVC casing from 13 to $23 \mathrm{ft}$ bls. The static water level was $0.5 \mathrm{ft}$ bls. An orange paint-can cap had to be removed from the well before logging. The video log shows a very dirty casing, debris at $15.5 \mathrm{ft}$ bls, and sand and silt on the bottom of well. 


\section{BE-1578 (MW-3-DOB)}

Only the borehole-video log was run in this well. The log shows the total depth is $69 \mathrm{ft}$ bls and it is screened with PVC casing from $49.5 \mathrm{ft}$ bls to the visible bottom. The static water level was $30.2 \mathrm{ft}$ bls. The borehole video log shows debris at $26 \mathrm{ft}$ bls, possibly indicating a high water level. The casing is chipped at $29.7 \mathrm{ft}$ bls, debris is seen at $67.1 \mathrm{ft}$ bls, and sand and silt on the bottom appear to contain PVC shreds.

\section{BE-1579 (MW-4-OB)}

Only the borehole-video log was run in this well. The log shows the total depth is $21 \mathrm{ft}$ bls and it is screened with PVC casing from 11 to $21 \mathrm{ft}$ bls. The static water level was $1.7 \mathrm{ft}$ bls. The boreholevideo log shows the well is clean with little debris or dirt and only slight sediment on the bottom.

\section{BE-1580 (MW-5-OB)}

Only the borehole-video log was run in this well. The log shows the total depth is $33 \mathrm{ft}$ bls and it is screened with PVC casing from 23 to $33 \mathrm{ft}$ bls. The static water level was $24.1 \mathrm{ft}$ bls. The boreholevideo log shows organic material growing on joint threads at $4.9 \mathrm{ft}$ bls, moisture and possible bacterial growth at the joint at $13 \mathrm{ft}$ bls, and stain marks at 16.6, 19.8, and $20.9 \mathrm{ft}$ bls that may indicate different static water levels. The PVC screen is stained and coated beginning at $26.2 \mathrm{ft}$ bls to bottom.

\section{BE-1581 (MW-5-DOB)}

Only the borehole-video log was run in this well. The log shows the total depth is $100 \mathrm{ft}$ bls and it is screened with PVC casing from approximately 80 to at least $100 \mathrm{ft}$ bls. The static water level was $55.1 \mathrm{ft}$ bls. The borehole video log shows white material that may be the bentonite used to seal the annulus between the borehole and the PVC casing coming from the joint at $52.5 \mathrm{ft}$ bls. The video shows possible bacteria staining bel ow $59 \mathrm{ft}$ bls that increases with depth. The PVC screen is stained and partly coated or clogged for its entire length.

\section{BE-1582 (MW-7-OB)}

Only the borehole-video log was run in this well. The log shows the total depth is $58 \mathrm{ft}$ bls and it is screened with PVC casing from 38 to $58 \mathrm{ft}$ bls. The static water level was $49.2 \mathrm{ft}$ bls. The boreholevideo log indicates possible seepage from the joint at $28 \mathrm{ft}$ bls. J oint threads are visible at the top of the screen at $38 \mathrm{ft}$ bls, indicating incomplete tightening. The video shows the casing is dirty and stained the entire length, especially bel ow $28 \mathrm{ft}$ bls. The screen is dirty and shows unknown deposits at 41.5 and $44 \mathrm{ft}$ bls; some silt or sand is on the well bottom. 


\section{BE-1583 (Wetzel)}

The caliper log shows the total depth of the borehole is $278 \mathrm{ft}$ and it is cased with 6-in.-diameter casing (fig. 10). The single-point-resistance log shows steel casing to $56 \mathrm{ft}$ bls. The static water level was $31.98 \mathrm{ft}$ bls. The caliper log shows only minor fractures throughout the open-hole interval and a minor constriction at $269 \mathrm{ft}$ bls. The caliper log shows the bottom $7 \mathrm{ft}$ of the borehole is filled with soft sediment. Under ambient conditions, the heat-pulse-flowmeter measurements indicated upward borehole flow at 60, 80, 100, 150, 200, 250, and $260 \mathrm{ft}$ bls (table 7). The borehole video shows near zero visibility from water level to $82 \mathrm{ft}$ bls, partial clearing near $82 \mathrm{ft}$ bls, and poor visibility below $150 \mathrm{ft}$ bls. The geophysical logs and the heat-pulse-flowmeter data indicate water enters the borehole through the fractures bel ow $260 \mathrm{ft}$ bls, moves upward, and exits the borehole through fractures at 84 and $57 \mathrm{ft}$ bls. If the water produced by the fractures below $260 \mathrm{ft}$ bls is contaminated, leaving this well as an open borehole may create cross-contamination of the shallow aquifer. A screen placed at 250-270 ft bls would include the water-producing fractures bel ow $260 \mathrm{ft}$ bls.

Table 7. Summary of heat-pulse-flowmeter measurements for borehole BE-1583 (Wetzel) at Crossley Farms Superfund Site, Berks County, Pennsylvania

[ft bls, feet below land surface; gal/min, gallons per minute]

\begin{tabular}{ccc}
\hline Depth (ft bls) & $\begin{array}{c}\text { Flow rate } \\
\text { under ambient } \\
\text { conditions } \\
\text { (gal/min) }\end{array}$ & $\begin{array}{c}\text { Flow direction } \\
\text { under ambient } \\
\text { conditions }\end{array}$ \\
\hline 50 & no flow & \\
60 & 0.06 & up \\
80 & .09 & up \\
100 & .26 & up \\
150 & .43 & up \\
200 & .32 & up \\
250 & .32 & up \\
260 & .33 & up \\
\hline
\end{tabular}




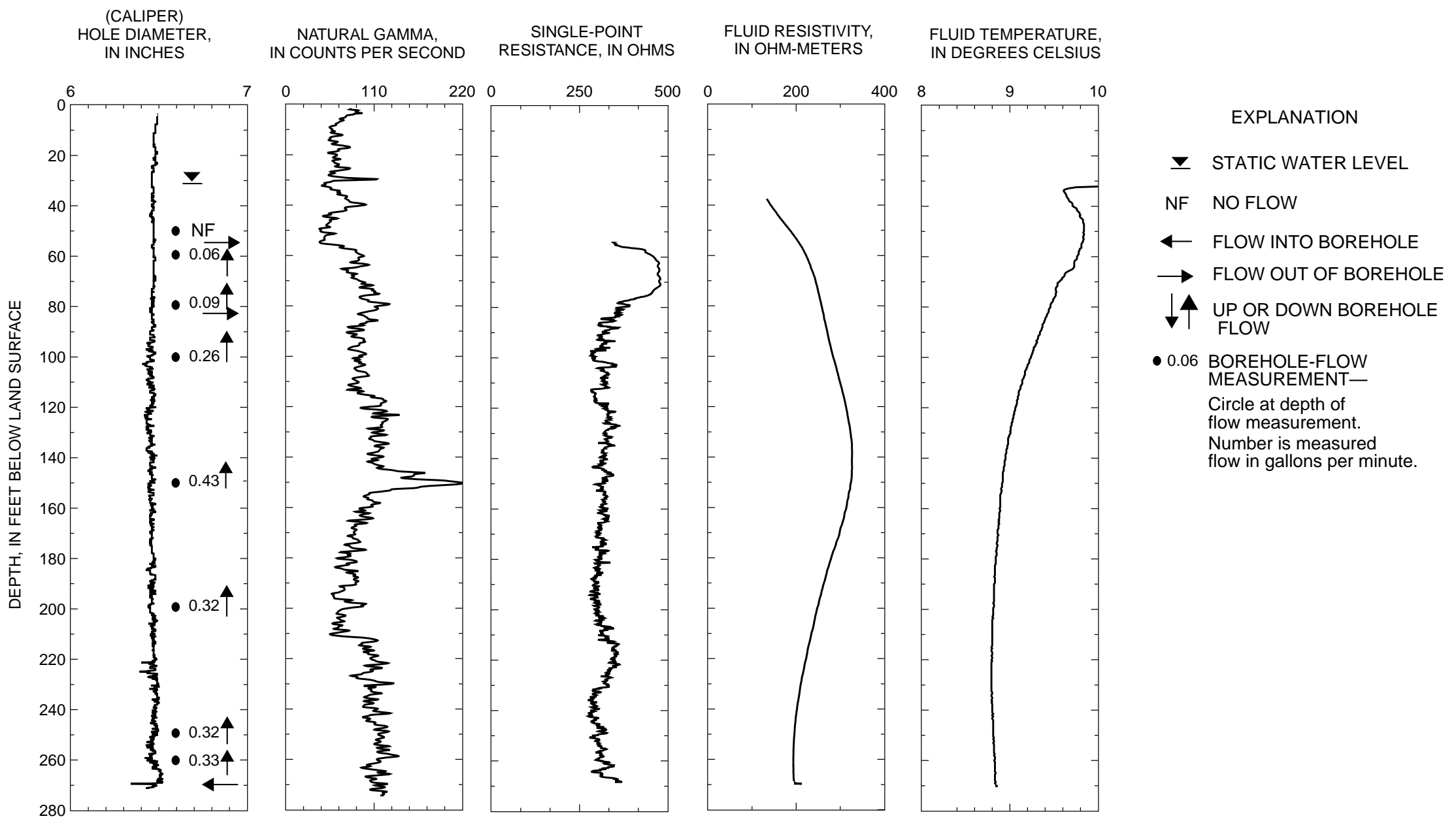

Figure 10. Borehole-geophysical logs for borehole BE-1583 (Wetzel), collected on May 6, 1997, Crossley Farms Superfund Site, Berks County, Pennsylvania. 


\section{BE-1584 (92-17)}

The caliper log shows the total depth of the borehole is $435 \mathrm{ft}$ and it is cased with 6-in.-diameter casing to approximately $54 \mathrm{ft}$ bls (fig. 11). The static water level was $3.64 \mathrm{ft}$ bls. The caliper log shows major fractures at 54.5-59, 162, and 276-278 ft bls and numerous minor fractures throughout the open-hole interval. The fluid-resistivity and fluid-temperature logs show changes in slope at approximately 60, 110, and $320 \mathrm{ft}$ bls. Under ambient conditions, the heat-pulse-flowmeter measurements indicated upward borehole flow at 64, 70, 80, 124, 150, 200, 264, 302, 350, and $401 \mathrm{ft}$ bls; downward flow at 88 and $100 \mathrm{ft}$ bls, and no flow at $420 \mathrm{ft}$ bls (table 8). The borehole video shows the water column is very cloudy with many suspended particles. Partial clearing does occur at 66-68 ft bls. The geophysical logs and the heat-pulse-flowmeter data indicate water enters the borehole through the fractures bel ow $400 \mathrm{ft}$ bls, at 320, 276-278, and about $130 \mathrm{ft}$ bls, moves upward, and exits the borehole through fractures at $102-117 \mathrm{ft}$ bls. Also, water enters the borehole through fractures at $83 \mathrm{ft}$ bls, moves upward and downward, and exits the borehole through fractures at 59 and $102-117 \mathrm{ft}$ bls, respectively. If the water produced by the fractures below $400 \mathrm{ft} \mathrm{bls}$, at 320, at 276-278, and approximately $130 \mathrm{ft}$ bls is contaminated, leaving this well as an open borehole may create cross-contamination of the intermediate or shallow aquifer.

Table 8. Summary of heat-pulse-flowmeter measurements for borehole BE-1584 (92-17) at Crossley Farms Superfund Site, Berks County, Pennsylvania

[ft bls, feet below land surface; gal/min, gallons per minute]

\begin{tabular}{ccc}
\hline Depth (ft bls) & $\begin{array}{c}\text { Flow rate } \\
\text { under ambient } \\
\text { conditions } \\
\text { (gal/min) }\end{array}$ & $\begin{array}{c}\text { Flow direction } \\
\text { under ambient } \\
\text { conditions }\end{array}$ \\
\hline 64 & 0.23 & up \\
70 & .07 & up \\
80 & .07 & up \\
88 & .28 & down \\
100 & .68 & down \\
124 & .80 & up \\
150 & .43 & up \\
200 & .38 & up \\
264 & .49 & up \\
302 & .42 & up \\
350 & .06 & up \\
401 & .06 & up \\
420 & no flow & \\
\hline
\end{tabular}




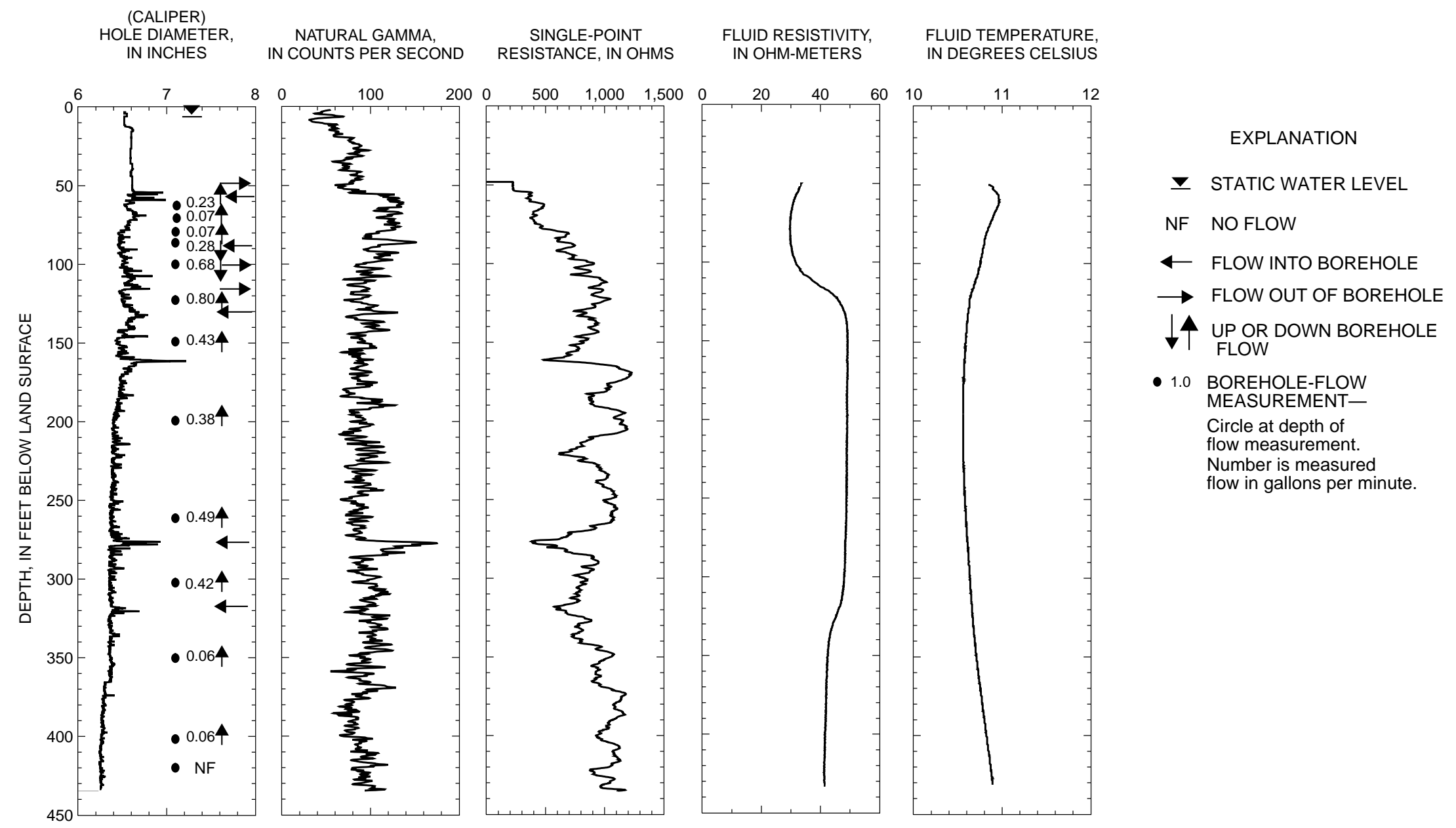

Figure 11. Borehole-geophysical logs for borehole BE-1584 (92-17), collected on May 8, 1997, Crossley Farms Superfund Site, Berks County, Pennsylvania. 


\section{CONCLUSIONS}

This report identifies water-producing zones, water-receiving zones, and intervals of vertical borehole flow and determines the condition of existing well construction by the use of geophysical logs, heat-pulse-flowmeter data, and video logs. These data will help evaluate horizontal and vertical distribution of any contaminated ground water migrating from known contaminant sources and the integrity of existing wells.

Boreholes located off the Crossley Farms Superfund Site, BE-1562 (MW-8R), BE-1563 (MW-7R), BE-1567 (MW-5R), and BE-1583 (Wetzel), are located down gradient from the Crossley Farms Superfund Site near the base of Blackhead Ridge and show upward ambient borehole flow. In these boreholes, water is produced through fractures between 90-270 ft bls, moves upward, and exits the borehole through fractures between $55-200 \mathrm{ft}$ bls, indicating that these boreholes are located in areas of ground-water discharge.

Borehole BE-1568 (MW-2DR) is deep and shows only minor upward flow near the bottom. BE-1571 (MW-1R), located on-site down gradient from the contaminant source, penetrates a fracture zone, is high yielding, and is the most contaminated borehole.

Flowmetered boreholes BE-1562, BE-1563, BE-1564, BE-1567, BE-1568, and BE-1583 all show minor vertical flow within the borehole. Generally, water is produced near the bottom of the borehole, regardless of depth, moves upward, and exits the borehole through fractures near the bottom of casing. The upper fluid-receiving fractures apparently depend on the depth of casing in each borehole. Heat-pulse-flowmeter data indicate all boreholes penetrate one to three water-bearing zones depending on well depth. Well yield apparently depends on chance interception of interconnected water-producing fractures.

The video logs were useful for casing inspection, especially for PVC-screened wells. Screen intervals were verified and potential construction problems were identified in several wells. The video logs show that most wells were cloudy with poor visibility that may be partially a result of logging activities. Visibility was so poor in wells BE-1571 and BE-1575 that depth of casing could not be determined. The video log shows that BE-1566 (MW4-R) has broken casing at $46 \mathrm{ft}$ bls.

\section{REFERENCES CITED}

Conger, R.W., 1996, Borehole geophysical logging for water-resources investigations in Pennsylvania: U.S. Geological Survey Fact Sheet 218-95, 4 p.

Halliburton NUS, 1995, Draft Remedial Investigation/Feasibility Study Project Operations PIan, Crossley Farms Site, Berks County, Pennsylvania: EPA Contract No. 68-W8-0037.

Keys, W.S., 1988, Borehole geophysics applied to ground-water investigations: U.S. Geological Survey Open-File Report 87-539, 305 p.

Keys, W.S., and MacCary, L.M., 1971, Application of borehole geophysics to water-resources investigations: U.S. Geological Survey Techniques of Water-Resources I nvestigations, book 2, chap. E1, 124 p.

Roy F. Weston/IT, 1988, Regional Hydrogeologic I nvestigation, Town of Hereford Site, Berks County, Pennsylvania: EPA Contract No. 68-03-3482.

Williams, J.H., and Conger, R.W., 1990, Preliminary delineation of contaminated water-bearing fractures intersected by open-hole bedrock wells: Groundwater Monitoring Review, Fall 1990, p. 118-121. 